\title{
Analisis Bauran Komunikasi Pemasaran Dalam Membangun Brand Loyalty Bar Kopi Seru
}

\author{
Yohanes . Wulan Purnama Sari \\ Yohanes.ik@stu.untar.ac.id,Wulanp@fikom.untar.ac.id \\ Fakultas Ilmu Komunikasi Universitas Tarumanagara
}

\begin{abstract}
study describes the analysis of marketing communication mix in building brand loyalty. This study uses a case study qualitative research method which uses two theories. The main theory is the Mixture of Marketing Communication Kotler \& Armstrong (2010) and Brand Loyalty Oliver (1999) as the theory of supporting authors. Social media and Word of mouth are a specific mixture of promotional tools that companies use to persuasively communicate consumer values and build relationships with consumers. marketing used Kopi Seru. The results of a study that discusses the existence of marketing communication with Kopi Seru in order to build Brand Loyalty from its newly developed brand.
\end{abstract}

Keywords: Brand Loyalty, Marketing Communication Mix, Kopi Seru

\begin{abstract}
Abstrak
Penelitian ini menjelaskan mengenai analisis Bauran komunikasi pemasaran dalam membangun brand loyalty. Penelitian ini menggunakan metode penelitian kualitatif studi kasus dimana menggunakan dua teori. Teori utama merupakan Bauran Komunikasi Pemasaran Kotler \& Armstrong (2010) dan Brand Loyalty Oliver (1999) sebagai teori pendukung penulis. Social media dan Word of mouth merupakan campuran spesifik dari alat-alat promosi yang digunakan perusahaan untuk secara persuasif mengkomunikasikan nilai konsumen dan membangun hubungan dengan konsumen .Dimana tujuan dari penelitian ini untuk memberitahukan kepada pembaca mengenai tingkatan pada Brand Loyalty Kopi Seru yang dihasilkan oleh bauran komunikasi pemasaran yang digunakan Kopi Seru. Hasil dari penelitian merujuk kepada adanya bauran komunikasi pemasaran oleh Kopi Seru guna membangun Brand Loyalty dari brand-nya yang baru berkembang.
\end{abstract}

Kata Kunci : Brand Loyalty, Bauran Komunikasi Pemasaran, Kopi Seru

\section{Pendahuluan}

Bisnis kopi di Indonesia mengalami pertumbuhan dan persaingan yang ketat. Saat ini terdapat banyak kedai kopi yang buka, tidak hanya di pusat perbelanjaan di ibu kota tetapi juga di sepanjang jalanan ibu kota. Semakin kompetitifnya persaingan tersebut mengakibatkan pentingnya strategi yang digunakan oleh pelaku bisnis untuk menarik target yang menjadi sasaran kedai kopi tersebut.

Merek yang dimaksud dan yang diteliti oleh penulis adalah Kopi Seru Jakarta. Salah satu di antara kedai kopi yang terletak di daerah Jakarta Utara, tepatnya di Jalan Boulevard Raya Kelapa Gading. Kopi Seru termasuk sebuah merek baru dalam industri kopi nusantara. Berdiri di akhir tahun 2018 lalu, kedai kopi ini 
dapat dikatakan memiliki keunikan tersendiri karena mereka memiliki idealisme yang cukup tinggi dengan mengusung konsep yang tidak biasa dan mengedepankan arti dari cara menikmati kopi itu sendiri. Tidak tersedianya WiFi untuk pengunjung dilakukan agar pelanggan yang datang memang dikhususkan untuk menikmati kopi dengan santai tanpa harus memikirkan pekerjaan dan dapat memunculkan interaksi antara konsumen dan baristanya.

seru memiliki tempat yang cukup sederhana. Sebuah konsep dengan ruangan kecil yang berisi bar yang di gabung bersama dengan Coin Loundry sebagai tempat barista untuk meracik kopi dan dikemas selayaknya ruang tamu di rumah, Desain interior yang digunakan oleh Kopi seru juga sederhana dan menarik, karena hanya menggunakan kayu dan kaca yang sesuai dengan slogan mereka yaitu "Seru-in aja kale"

Kopi Seru adalah salah satu kedai kopi yang terbilang pendatang baru. Sebagai pendatang baru di tengah-tengah sekian banyak kedai kopi yang sudah ada, bagaimana Kopi seru menghadapi para pesaingnya itu, bagaimana Kopi seru dapat merebut pasar.

\section{Metode Penelitian}

Metode penelitian yang digunakan oleh penulis adalah metode penelitian kualitatif. Menurut Strauss dan Corbin (1997), metode penelitian kualitatif adalah jenis penelitian yang menghasilkan penemuan-penemuan yang tidak dapat dicapai dengan menggunakan prosedur-prosedur statistik atau cara-cara lain dari kuantifikasi (pengukuran). Penelitian kualitatif secara umum dapat digunakan untuk penlitian tentang kehidupan masyarakat, sejarah, tingkah laku, fungsionalisasi organisasi, aktivitas sosial, dan lain-lain (Sujarweni, 2014).

Menurut Sugiyono (2010), penelitian kualitatif adalah cara ilmiah untuk mendapatkan data valid dengan tujuan yang dapat ditemukan, dikembangkan dan dibuktikan oleh pengetahuan tertentu sehingga pada gilirannya dapat digunakan untuk memahami, memecahkan, serta mengantisipasi masalah dalam bidang pendidikan.

Menurut Leedy \& Ormrid; Patton; Saunders, Lewis \& Thornhill yang dikutip oleh Sarosa (2012), penelitian kualitatif adalah penelitian yang mencoba memahami fenomena dalam setting dan kontek naturalnya (bukan di dalam laboratorium) dimana peneliti tidak berusaha untuk memanipulasi fenomena yang diamati.

Dalam penelitian ini penulis memilih penelitian dengan metode kualitatif karena penulis ingin mengetahui komunikasi pemasaran terhadap tingkatan Brand Loyalty dari konsumen kopi seru. Melalui metode kualitatif, penulis dapat menggali lebih dalam mengenai hal yang ingin penulis teliti menggunakan metode wawancara mendalam dan observasi.

\section{Hasil Temuan dan Diskusi}

Dalam penelitian ini penulis akan melakukan wawancara dan observasi mendalam untuk memperoleh data kualitatif yang diperlukan dan sesuai dengan penelitian. Bauran komunikasi pemasaran (marketing communication mix) merupakan gabungan dari lima model komunikasi dalam promosi yaitu: advertising, sales promotion, public relations, personal selling, dan direct marketing. Demikian pula halnya dengan events dan exhibitions. Keduanya merupakan bagian dari 
marketing communication mix yang dikembangkan oleh bagian sales promotion. Komunikasi yang digunakan dalam kegiatan sales promotion membutuhkan media promosi seperti flyer, banner, poster, catalogue dan corporate profile. Sedangkan pada personal selling, media tersebut juga dibutuhkan khususnya dalam penawaran suatu produk kepada konsumen secara tatap muka (Soemanagara, 2006).

Perusahaan harus berusaha keras untuk berkomunikasi dan membangun hubungan dua arah. Bauran pemasaran yang terbaru lebih mengutamakan komunikasi untuk pelanggan dibanding bagaimana promosi yang terus menerus, hal ini bertujuan untuk menciptakan komunikasi pemasaran yang interaktif bagi pelanggan. Karena saat ini pelanggan sudah lebih cerdas dan berhati-hati dalam mempercayai suatu promosi dari sebuah produk. Pelanggan akan lebih senang untuk merasa terlibat dan memiliki interaksi yang bermakna dengan suatu produk tertentu. Sehingga membangun komunikasi dua arah akan menjadi cara terbaik untuk mengetahui apa yang terbaik bagi pelanggan.

Penjelasan di atas dapat mendasari pemikiran bahwa bauran komunikasi pemasaran digunakan oleh perusahaan untuk mencapai tujuan perusahaan yang tidak semata-mata untuk meraih keuntungan, namun untuk memfasilitasi kebutuhan dan keinginan konsumen. Terdapat 12 jenis dari bauran komunikasi pemasaran, yaitu: Advertising, Direct Marketing, Public Relation, Sales Promotion, Sponsorship, Exhibition, Packaging, Merchendising, Selling and Sales Management, Social Media, Websites, dan Word of Mouth.

Dalam upaya menjangkau target marketnya dan membangun brand loyalty, Kopi Seru hanya menjalankan dua bauran komunikasi pemasaran untuk mendapatkan feedback dari customernya. Beberapa bauran komunikasi pemasaran tersebut adalah sebagai berikut:

\section{Social Media}

Social Media bertujuan untuk memberikan wadah bagi target market untuk berkomunikasi dan mendapatkan informasi berupa berita, video, foto, dalam bentuk viral. Kopi Seru menggunakan media sosial Instagram karena instagram merupakan salah satu media sosial yang banyak digunakan oleh masyarakat luas.

Informan:

"Pakai instagram, karena instagram sekarang paling bagus menurut saya. Banyak anak muda, dan target market kita banyak pengguna instagram. Kita juga bisa menjangkau calon customer yang belum bisa kita jangkau. Selain itu instagram kan berupa gambar, gambar itu bisa menceritakan sesuatu yang dibantu oleh caption-nya.

"Memaksimalkan konten instagram dari foto, isi kontennya, beberapa kita tonjolkan kayak suasana tempat, produk kita, dan kita lagi ada acara apa sih. Biar customer tau apa aja aktivitas yang kita lakukan.”

Kesimpulan yang dibuat penulis adalah social media yang digunakan oleh Kopi Seru bertujuan untuk menjangkau target pasar yang belum bisa dicapai Kopi Seru. Cara untuk menjangkaunya adalah dengan memaksimalkan konten dari akun media sosial tersebut dengan mengangkat suasana/ ambiance serta produk dan event-event yang diadakan oleh Kopi Seru. 


\section{Word of Mouth}

Aspek terakhir yang digunakan oleh Kopi Seru adalah Word of Mouth. Word of mouth yang dilakukan oleh dimulai dengan memberi servis yang baik terhadap kosumen, kemudian membangun relasi terhadap konsumen, kemudian membentuk komunitas di dalam lingkungan Kopi Seru. Hal itu terbukti dari kutipan wawancara sebagai dengan informan sebagai berikut.

Informan:

"Sudah pasti banget, saya dari awal meyakinkan bahwa word of mouth lebih kuat karena langsung kepada buyer atau customer. Kita di sini kasih servis yang terbaik buat customer. Dengan kasih greeting yang ramah, kita juga ajak si customer untuk ngobrol, kita tanyain gimana produknya, dan jangan lupa selalu say thanks setiap customer mau pergi. Dengan hal baik yang kita terapin itu gue yakin pasti mereka akan balik lagi sih."

"Banyak banget impact dari word of mouth yang sudah kita lakukan. Tagline kita kan "kopi di seruin aja", customer disini kita perlakukan seperti teman sendiri jadi mereka berasa nyaman, berasa ngopi di ruang tamu dengan santai, melepas penat gitu. Kemudian kita membentuk enggagement-nya itu kita bikin grup untuk loyal customer yang datang kekopi seru."

Sesuai dengan Kotler (2006) mendefinisikan word of mouth sebagai "personal communication about a product between target buyers and neighbors, friends, family members, and associates." (sebuah komunikasi personal mengenai sebuah produk yang terjalin di antara target pembeli dengan tetangga, teman-teman, anggota keluarga, dan rekan kerja). Kopi Seru menerapkan bauran komunikasi pemasaran word of mouth melalui target market mereka hingga akhirnya sampai kepada kerabat-kerabat dari target market tersebut.

penulis akan memetakan analisis berdasarkan hasil dari wawancara mendalam kepada narasumber dengan teori-teori yang digunakan penulis dalam penelitian ini, agar penulis dapat melihat bagaimana dua bauran komunikasi pemasaran yang digunakan oleh Kopi Seru membangun brand loyalty di mata konsumennya yang telah dibangun oleh Kopi Seru. hasil dari analisis yang didapat sebagai berikut :

\section{Social Media}

Berdasarkan wawancara yang dilakukan dengan informan Kopi Seru hanya menggunakan media sosial Instagram dalam strategi komunikasi pemasaran yang dilakukannya. Media sosial Dilihat dari banyaknya pengguna Instagram, maka media sosial tersebut dianggap paling bagus untuk meraih target market. Kopi Seru memaksimalkan isi konten media sosialnya dengan pemilihan foto yang menjelaskan produk, ambiance serta aktivitas yang dilakukan oleh pihak Kopi Seru

Berdasarkan hasil wawancara, seluruh responden tahu dan mengikuti akun media sosial milik Kopi Seru. Mereka menganggap bahwa Kopi Seru aktif di dalam media sosial, memberikan informasi mengenai acara-acara yang akan diadakan atau diikuti oleh Kopi Seru, serta memberi tahu menu baru yang mereka tawarkan. Konten-konten di media sosialnya dianggap menarik dan membantu orang-orang untuk mengenal Kopi Seru. 
Sesuai dengan definisi social media (Barker, dkk) "a collective group of web properties whose content is primarily published by users, not direct employees of the property." (sebuah kelompok kolektif dari property web yang kontennya secara primer diterbitkan oleh pengguna dan bukan karyawan-karyawan dari property tersebut). Dimana Kopi Seru menerbitkan konten-konten untuk disampaikan kepada target pasar dan konsumen mereka.

Melihat hasil wawancara, social media dalam bauran komunikasi pemasaran yang digunakan oleh Kopi Seru dapat terbilang baik dalam membangun brand loyalty.

\section{Word Of Mouth}

Dari hasil wawancara dengan infroman, bauran komunikasi pemasaran word of mouth diyakini oleh Kopi Seru lebih kuat daripada bauran komunikasi pemasaran lainnya. Word of mouth dianggap lebih efektif karena informasi langsung diterima kepada calon customer. Kopi Seru selalu memberikan servis yang baik agar konsumennya merasa nyaman dan akan datang lagi membawa teman atau kerabatnya. Kemudian Kopi Seru juga membuat sebuah grup chat yang berisikan loyal customer mereka agar bisa menyebarkan informasi mengenai Kopi Seru.

Berdasarkan hasil wawancara, mayoritas responden pernah mendapatkan infromasi mengenai Kopi Seru dari orang lain. Informasiinformasi yang didapatkan biasanya mengenai produk baru yang dikeluarkan oleh Kopi Seru serta ambiance/suasana kedai Kopi Seru.

Word of mouth dianggap sebagai kekuatan yang paling kuat,berpengaruh, dan persuaif dalam marketplace. Word of mouth berbicara mengenai penyampaian pengalaman secara mandiri, sehingga informasi yang diperoleh memiliki kredibilitas dan efisien dari segi waktu (Silberman, 2001). Hal ini sesuai dengan yang telah diyakini oleh Kopi Seru dalam melakukan bauran komunikasi pemasarannya.

Melihat hasil wawancara, strategi komunikasi pemasaran word of mouth yang diterapkan Kopi Seru sangat efektif membangun brand loyalty dari Kopi Seru.

\section{Kesimpulan}

Berdasarkan penelitian yang telah penulis lakukan, penulis menyimpulkan bahwa strategi komunikasi pemasaran telah dijalankan dengan baik oleh manajemen Kopi Seru. Tetapi dalam implementasinya Kopi Seru membatasi strategi komunikasi pemasaran mereka pada, social media, dan word of mouth.

Loyalty yang dimiliki oleh customer berdasarkan penelitian penulis adalah bahwa social media dan word of mouth memegang peranan terbesar dalam membangun brand loyalty terhadap konsumennya. Dan juga hal ini terbukti dari hasil wawancara yang telah dilakukan oleh penulis, dimana kebanyakan dari responden mengetahui Kopi seru dari teman atau kerabatnya.

\section{Ucapan Terima Kasih}

Ucapan terima kasih ditujukan kepada Fakultas Ilmu Komunikasi Universitas Tarumanagara, dan pembimbing Wulan Purnama Sari, S.Ikom, M.Si dan juga kepada 
yang berkooperatif sebagai objek wawancara dalam laporan penelitian ini, serta kepada semua pihak yang sudah ikut terlibat dan membantu melancarkan penelitian ini. Tanpa pertolongan dari orang-orang yang ikut serta dalam penelitian ini, penelitian ini tidak dapat terealisasikan. Penulis bahwa penelitian ini masih banyak sesuatu yang kurang. Namun penulis berharap penelitian ini dapat berguna untuk semua orang yang membutuhkannya baik untuk akademis ataupun praktik.

\section{Daftar Pustaka}

Barker, M, Baker, D, Bormann, N, \& Neher, K. (2013), Social Media Marketing: A Strategic Approach, South-Western Cengage Learning, Mason, OH. Clow, Kenneth. E. \& Baac, Donald. (2007), Integrated Advertising, Promotion, and Marketing Communications", USA.

Durianto,Sugiarto dan Tony Sitinjak, (2001). Strategi Menaklukkan Pasar Melalui Riset Ekuitas dan Perilaku Merek , PT. Gramedia Pustaka Utama,Jakarta.

Kotler, P \& Armstrong, G (2010), Principles of Marketing, Pearson Education, Upper Saddle River, New Jersey.

Morissan MA (2010), Periklanan Komunikasi Pemasaran Terpadu, Kencana, Jakarta.,

Prisunanto, Ilham, (2006), Komunikasi Pemasaran: Strategi dan Taktik

Shimp, T (2007), Integrated advertising, promotion, and marketing communication, Thomson South-Western, Singapore 